\begin{tabular}{|l|l|l||}
\hline \multicolumn{2}{|c|}{ PublisherInfo } \\
\hline \hline PublisherName & $:$ & BioMed Central \\
\hline \hline PublisherLocation & $:$ & London \\
\hline \hline PublisherImprintName & $:$ & BioMed Central \\
\hline \hline
\end{tabular}

\title{
Review: Acute necrotising pancreatitis
}

\begin{tabular}{||l|l|l||}
\hline \multicolumn{2}{|c||}{ ArticleInfo } \\
\hline \hline ArticleID & $:$ & 4144 \\
\hline \hline ArticleDOI & $:$ & $10.1186 /$ ccf-1999-881 \\
\hline \hline ArticleCitationID & $:$ & 881 \\
\hline \hline ArticleSequenceNumber & $:$ & 81 \\
\hline \hline ArticleCategory & $:$ & Paper Report \\
\hline ArticleFirstPage & $:$ & 1 \\
\hline \hline ArticleLastPage & $:$ & 2 \\
\hline \hline & $:$ & RegistrationDate : 1999-7-7 \\
ArticleHistory & $:$ & OnlineDate $:$ 1999-7-7 \\
\hline \hline ArticleCopyright & $:$ & Current Science Ltd1999 \\
\hline \hline ArticleGrants & $:$ & \\
\hline \hline ArticleContext & $:$ & 130541111 \\
\hline \hline
\end{tabular}




\section{Keywords}

Nutrition, octreotide, pancreatitis, protease inhibitors, selective decontamination, surgery

\section{Comments}

Acute necrotising pancreatitis (ANP) has a high mortality, but although various treatments are utilised, they lack evidence of any real benefit to the patient. This important review takes an evidence based approach to the methods of diagnosis, surgical intervention, drug therapies, use of antibiotics and modes of nutrition proposed for the management of ANP.

Unfortunately, it concludes that there are very little hard data to support the use of novel drug therapies aimed at resting the pancreas, and that good supportive care remains the mainstay of treatment. Surgery should be reserved for those where the diagnosis is in doubt, and in the presence of infected pancreatic necrosis. The myth that these patients cannot be enterally fed is highlighted and the introduction of jejeunal feeding, at the earliest possible opportunity, is suggested.

\section{References}

1. Wyncoll DL: The management of severe acute necrotising pancreatitis: an evidence based review of the literature. Intensive Care Med. 1999, 25: 146-156. 